\title{
Comparing vowel hiatus resolution in ciNsenga and chiShona: An Optimality Theory analysis
}

\author{
Maxwell Kadenge \\ Department of Linguistics, University of the Witwatersrand, South Africa \\ E-mail: maxwell.kadenge@wits.ac.za \\ Silvester Ron Simango \\ Department of English Language and Linguistics, Rhodes University, South Africa \\ E-mail: r.simango@ru.ac.za
}

\begin{abstract}
This article seeks to contribute to typology by presenting a formal comparative analysis of repair strategies used to resolve vowel hiatus in ciNsenga and chiShona. In these two languages, hiatus resolution is sensitive to phonology and morphosyntax such that hiatus resolution strategies apply differently depending on the phonological and morphosyntactic context. Across the prefix + noun stem boundary and within the Inflectional Stem, $V_{1}$ undergoes "resyllabification" (Myers 1987:222) in the form of glide formation, secondary articulation and elision. An interlinguistic difference occurs when $\mathrm{V}_{2}$ is MacroStem-initial: in ciNsenga, hiatus resolution is blocked but in chiShona spreading is triggered. We follow Mudzingwa (2010) in proposing that resyllabification in chiShona is blocked at the Prosodic Stem edge by an alignment constraint (ALIGNL-PSTEM) that requires the left edge of a Prosodic Stem to align with the left edge of an onset-full syllable. We argue that resyllabification and glide epenthesis in ciNsenga are blocked when $\mathrm{V}_{2}$ is MacroStem-initial because ALIGN (ROOTVERB, L, $\sigma, L$ ) outranks ONSET and ALIGNL-PSTEM. Crucially, this article demonstrates that whilst vowel hiatus resolution is categorical in chiShona, it is domain-specific in ciNsenga.
\end{abstract}

Keywords: CiNsenga, ChiShona, hiatus resolution, Optimality Theory, resyllabification

\section{Introduction}

Hiatus - a heterosyllabic sequence of adjacent vowels - has been a subject of considerable empirical and theoretical discussion. Some languages permit vowel hiatus freely, others allow it in some limited contexts, and still others disallow it completely (see, for example, Myers 1987; Casali 1997, 1998, 2011; Mudzingwa 2010, 2013; Mudzingwa and Kadenge 2011; Simango and Kadenge 2014 and the references contained in these sources). Hawaiian is a typical example of a language that allows vocalic hiatus freely, as in the following examples (Senturia 1998:26, Casali 2011): 
$\begin{array}{lll}\text { (1) } & \text { [ko.a.na }] & \text { 'space' } \\ (2) & {[\text { ku.a }]} & \text { 'back' } \\ (3) & {[\text { hu.i.na }]} & \text { 'sum' } \\ (4) & {[\text { ko.e.na }]} & \text { 'remainder' }\end{array}$

Like most southern Bantu languages, ciNsenga and chiShona have highly agglutinative morphology, and morphosyntactic concatenation (both prefixation and suffixation) often results in vocalic hiatus, i.e. $\mathrm{V}_{1} . \mathrm{V}_{2}$ sequences in which $\mathrm{V}_{2}$ is onsetless. Onsetless syllables are marked and the resolution of vocalic hiatus is generally attributed to the high ranking markedness constraint ONSET, which requires syllables to have onsets, thus disallowing heterosyllabic $\mathrm{V}_{1} . \mathrm{V}_{2}$ sequences which would arise where hiatus is maintained (Casali 2011, Ito 1989, Prince and Smolensky 2004).

Repair strategies for resolving vowel hiatus include glide formation, secondary articulation, elision, coalescence, consonant epenthesis and diphthong formation (Casali 1997, 1998, 2011; Mtenje 2007; Mudzingwa 2013; Simango and Kadenge 2014). The main aim of this article is to present a formal comparative analysis of hiatus resolution strategies that are active in ciNsenga and chiShona, showing under what circumstances potential vocalic hiatus occurs, how it is resolved and the constraints involved in different morphosyntactic and phonological contexts.

It is common to find two or more different hiatus resolution strategies at work in the same language (Casali 2011). Independent studies have shown that vocalic hiatus is dispreferred in ciNsenga (Simango and Kadenge 2014) and chiShona (Kadenge 2010; Mudzingwa 2010, 2013; Mudzingwa and Kadenge 2011). CiNsenga uses three repair strategies to resolve hiatus, namely glide formation, secondary articulation and elision (Miti 2001, Simango and Kadenge 2014), while chiShona uses five repair strategies: glide formation, secondary articulation, elision, vowel coalescence and glide epenthesis (Kadenge 2010, Mudzingwa 2010, Mudzingwa and Kadenge 2011). As will become clearer below, the two languages show that different repair strategies are operative in different morphosyntatic and phonological contexts. For example, in chiShona, hiatus in nominals - i.e. across the prefix + stem boundary - is resolved by glide formation, secondary articulation and elision (Myers 1987, Mkanganwi 1995, Mudzingwa 2010, Mudzingwa and Kadenge 2013) ${ }^{1}$. The same resyllabification strategies apply in verbs but exclusively within the Inflectional Stem, across the subject prefix and tense-aspect-mood (TAM) boundary (Myers 1987, Downing and Kadenge 2014). Across Prosodic Stem boundaries, hiatus is resolved through glide epenthesis (Mudzingwa 2010, Downing and Kadenge 2014). Within the clitic-group, hiatus is resolved by coalescence (Harford 1997, Kadenge 2010, Mudzingwa 2010, Mudzingwa and Kadenge 2013, Mudzingwa 2013).

In ciCewa, vowel elision targets $V_{1}$ in prefix positions but $V_{2}$ in suffix positions (Mtenje 1992, Casali 1997) ${ }^{2}$. In chiShona, vowel elision targets $V_{1}$ irrespective of whether it is part of the prefix or the stem (Mudzingwa and Kadenge 2011, Mudzingwa 2013). The elimination of vowel hiatus creates an onset for $\mathrm{V}_{2}$. As mentioned earlier, this article is focused on comparing how different morphosyntactic and phonological domains trigger different hiatus resolution strategies in ciNsenga and chiShona. We account for cross-linguistic differences between these

\footnotetext{
${ }^{1}$ Following Fortune (1980), Mkanganwi (1995), Mudzingwa (2010) and Mudzingwa and Kadenge (2011), we use the term "nominal" here to refer to a lexical class that includes nouns, adjectives, quantitatives, enumeratives, selectors and possessive words.

${ }^{2}$ But see Simango and Kadenge (2014) for a counter-argument against $\mathrm{V}_{2}$ deletion.
} 
two languages using the concept of 'factorial typology' which predicts that typological variation is a consequence of different rankings of the same set of constraints (Prince and Smolensky 2004).

The remainder of this article is organised as follows: $\S 2$ briefly discusses the geographical location and genetic affiliation of ciNsenga and chiShona. It also presents vocalic inventories, syllable structures and morphosyntactic characteristics of the two languages as background to the analysis. In $\S 3$ we discuss the main tenets of Optimality Theory (OT) underpinning the data analysis in this article. This is followed in $\S 4$ by a formal analysis of glide formation, secondary articulation and elision. $\S 5$ looks at vocalic hiatus across the Prosodic Stem, and $\S 6$ presents the conclusion.

\section{Background}

CiNsenga is spoken in an area that straddles the Zambia-Malawi border around the districts of Chipata (Zambia) and Mchinji (Malawi), while chiShona is spoken mainly in the Mashonaland provinces of Zimbabwe. The variety of chiShona that we focus on in this article is chiZezuru, spoken in the Chikomba district of the Mashonaland East province; the dialect of ciNsenga that we analyse, also known as ciNgoni, is spoken by the Ngoni people. The latter originally spoke a variant of isiZulu, but the community has undergone significant language shift over time as a result of heavy influence from the Nsenga and other linguistic communities (see Simango 2006, 2012, 2013).

Like most southern Bantu languages, the vowel systems of ciNsenga and chiShona consist of five phonemic monophthongs /i e a o $\mathrm{u} /$. Vowel length is non-contrastive and predictable in these languages. The vowel of the penultimate syllable is always lengthened when the word is in utterance-final position (cf. Miti 2001, Fortune 1980). Both languages do not allow closed syllables and complex onsets. Prenasalised consonants and secondary articulations in these languages constitute single $\mathrm{C}$ segments, not consonant clusters (see Simango and Kadenge 2014, Mkanganwi 1995, Rogers 2009 and Mudzingwa 2010 for related discussions). In both languages, prefixes typically have a $(\mathrm{C}) \mathrm{V}$ pattern whereas suffixes have an invariant $\mathrm{VC}$ structure. Onsetless syllables occur in these languages but their occurrence is restricted to the word-initial position. In ciNsenga, unlike in chiShona, some onsetless syllables do occur wordmedially but only when $\mathrm{V}_{2}$ is MacroStem-initial.

Since different hiatus resolution strategies operate in different morphosyntatic domains, it is essential that we briefly illustrate the morphosyntatic structures of ciNsenga and chiShona nominals and verbs. A noun in Bantu languages is typically made up of a prefix + stem, as shown in Figure 1: 


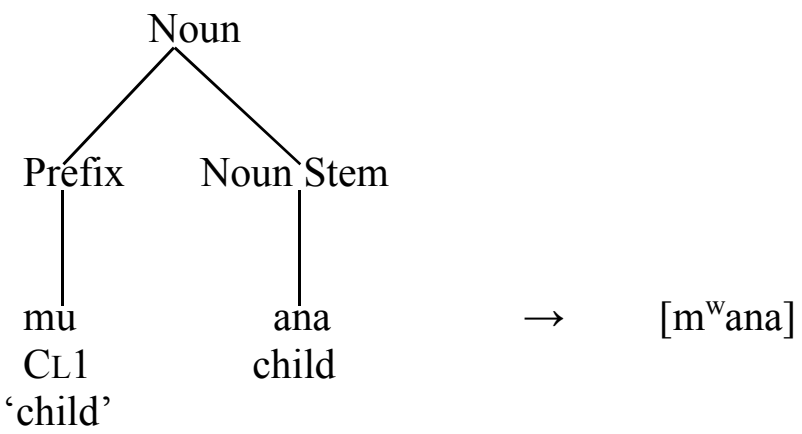

Figure 1. The morphological structure of the Bantu noun

One notable feature of ciNsenga and chiShona nominal prefixes is that they lack overt augments, the latter of which are found in other Bantu languages such as isiZulu and isiXhosa (see Miti 2001, Mudzingwa and Kadenge 2013). In chiShona and ciNsenga nominals, vowel hiatus across the prefix + stem domain is resolved through glide formation, secondary articulation and elision.

CiNsenga and chiShona verbs have morphosyntactic structures that are typical of Bantu languages; the complexity of Bantu verbal morphology is illustrated in Figure 2 below (Downing and Kadenge 2014:4) ${ }^{3}$ :
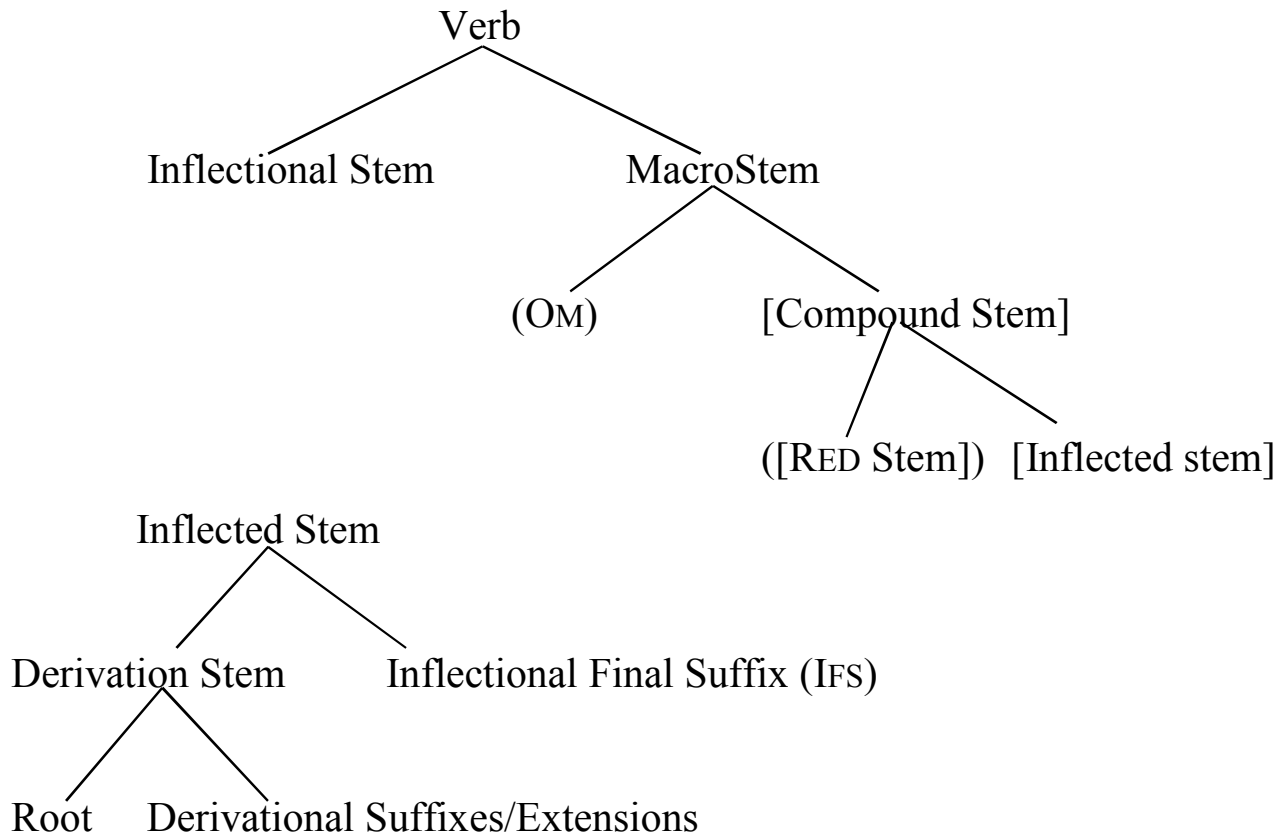

Figure 2. The morphological structure of the Bantu verb

There is vast phonological and morphological evidence for the various constituencies of the verb given in Figure 2 (see, for example, Myers 1987, Downing 2006, Mudzingwa 2010,

\footnotetext{
${ }^{3}$ See also Good (2005), Mchombo (1999), Mudzingwa (2010), Simango (2009) and Zerbian (2012) for various versions of this representation.
} 
Downing and Kadenge 2014). Previous studies have shown that, in Bantu languages, different morphosyntatic domains trigger different hiatus resolution strategies (see, for example, Myers 1987, Mudzingwa 2010, Simango and Kadenge 2014). The Inflectional Stem consists of subject- and TAM markers whereas the MacroStem comprises the object marker and the Inflected Verb Stem (see also Myers 1987, Mudzingwa 2010). In verbs, vowel hiatus typically occurs within the Inflectional Stem, across the subject marker and any of the TAM elements, and it is resolved through one of three resyllabification processes: glide formation, secondary articulation and elision. What is interesting is that in ciNsenga hiatus resolution is blocked across the Inflectional Stem and MacroStem boundary (Simango and Kadenge 2014) while in chiShona it is resolved through glide epenthesis (Kadenge 2010, Mudzingwa 2010, Downing and Kadenge 2014). To meaningfully account for these facts, we need to briefly sketch out the main tenets of OT which are relevant to our analysis.

\section{Optimality Theory}

The analysis that follows is couched within OT as developed by Prince and Smolensky (2004), among many others. It also draws on analytical insights from a generative CV-phonology model of syllable structure (Clements and Keyser 1983), Moraic Phonology (Hayes 1989) and Feature Geometry (Clements and Hume 1995).

OT is a constraint-based theory which holds that Universal Grammar (UG) consists of a set of constraints on structural well-formedness and that individual grammars are constructed out of this set of constraints. One of the major formalisms of this theory that we utilise here is factorial typology which predicts that interlinguistic variation is due to different rankings of the same set of constraints. This assumption has provided fertile ground for typological research in phonology and has been expanded to other aspects of grammar in recent years. The basic principles of OT (cf. Kager 1999:17) are as follows:

- UNIVERSALITY

Constraints are universal

- Violability

Constraints are violable, but violation must be minimal

- Optimality

An Output is optimal when it incurs the least serious violations of a set of constraints, taking into account their hierarchical ranking

- DOMINATION

The higher ranked of a pair of conflicting constraints takes precedence over the lowerranked one

In an OT grammar, cross-linguistic universals come about because constraints are universal, and cross-linguistic differences come about because constraints can be ranked differently. The constraints in OT fall into two broad categories, namely markedness constraints and faithfulness constraints. Markedness constraints rule out difficult or complex (marked) surface structures, while faithfulness constraints require underlying representations (inputs) and surface representations (outputs) to match. Contrast is preserved when faithfulness outranks markedness; alternations occur when markedness outranks faithfulness. 
Marked onsetless syllables in ciNsenga and chiShona are what trigger alternations in the form of hiatus resolution strategies. The interaction of faithfulness and markedness constraints with respect to ranking determines the optimal analysis of any given input (Prince and Smolensky 2004). The relevant constraints are motivated as required at each point in our analysis. In the following section, we examine and compare what happens when affixation creates vocalic hiatus in ciNsenga and chiShona.

\section{Hiatus resolution in ciNsenga and chiShona: A comparison}

As mentioned previously, in ciNsenga and chiShona, vocalic hiatus is dispreferred and is resolved through glide formation, secondary articulation, deletion and spreading (glide epenthesis). We follow Rosenthall (1997), Mudzingwa (2010, 2013) and Mudzingwa and Kadenge (2011) in proposing that glide formation, which results in mora loss, is the default or primary strategy as it shows least violation of faithfulness from the input; secondary articulation, which results in moraand root-node loss, is the second best strategy because it preserves the V-Place node of $\mathrm{V}_{1}$, while elision is the least preferred strategy because it dispenses with all the features of $V_{1}$, that is, its mora, V-Place node and root node. As will be shown in the following sections, the operations of glide formation, secondary articulation and elision in ciNsenga and chiShona are similar. In nouns and within the Inflectional Stem, hiatus is resolved through glide formation, secondary articulation and elision. However, in verbs, when $\mathrm{V}_{2}$ is stem-initial, chiShona triggers glide epenthesis and ciNsenga blocks hiatus resolution.

\subsection{Glide formation}

Glide formation is one of the most common repair strategies for resolving vocalic hiatus in ciNsenga and chiShona. It occurs when $\mathrm{V}_{1}$ is a high vowel, and this high vowel loses its moraicity by being turned into a glide which serves as an onset for $\mathrm{V}_{2}$. A non-high $\mathrm{V}_{1}$ is deleted without compensatory lengthening. If $\mathrm{V}_{1}$ is $/ \mathrm{i} /$, it is turned into the palatal glide [j]; however if $\mathrm{V}_{1}$ is $/ \mathrm{u} /$, it is turned into the labio-velar glide [w]. Thus, the resultant [j] and [w] are derived glides because they are surface or positional variants of underlying vowels (Rosenthall 1994). This complementary distribution is not surprising as high vowels and glides share the same feature content except that the former are moraic and the latter are not. As shown in Figure 3 below (adapted from Rosenthall 1994 and 1997), a glide is a high vocoid linked directly to the syllable node and a vowel is a high vocoid linked to a mora.
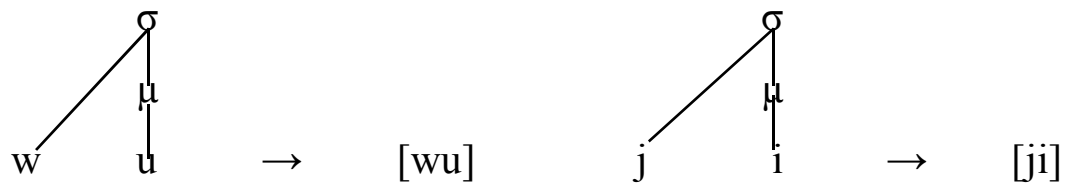

Figure 3. High glide/vowel distinction

Figure 4 is an illustration of the glide formation process, which involves a high vowel losing its mora or gliding before another vowel. 

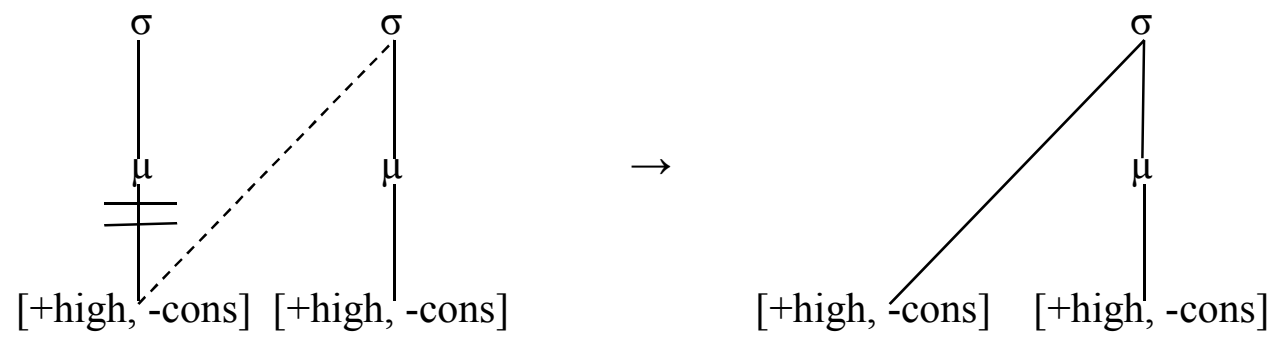

Figure 4. Glide formation

Glide formation occurs in the formation of possessive pronouns and quantitatives, as shown in Table 1 below. Most of these words are cognates found in ciNsenga and chiShona with the same form and meaning.

Table 1. Glide formation in possessive pronouns and quantitatives

\begin{tabular}{|c|c|c|c|c|c|c|c|}
\hline \multicolumn{4}{|c|}{ ChiShona } & \multicolumn{4}{|c|}{ CiNsenga } \\
\hline & Underlying & Surface & Meaning & & Underlying & Surface & Meaning \\
\hline (5) & $\begin{array}{l}/ \mathrm{u}-\mathrm{a}^{\mathrm{p}} \mathrm{gu} / \\
\text { CL1-mine }\end{array}$ & {$\left[w a^{y} g u\right]$} & 'mine' & (12) & $\begin{array}{c}\text { /u-ako/ } \\
\text { CL1-yours }\end{array}$ & [wako] & ‘yours' \\
\hline (6) & $\begin{array}{c}\text { /u-ega/ } \\
\text { CL1-alone }\end{array}$ & [wega] & ‘alone' & (13) & $\begin{array}{c}\text { /u-eka/ } \\
\text { CL3-only }\end{array}$ & [weka] & 'only' \\
\hline (7) & $\begin{array}{l}\text { /u-ose/ } \\
\text { CL3-all }\end{array}$ & [wose] & 'all' & (14) & $\begin{array}{l}/ \mathrm{u}-\mathrm{o}^{\mathrm{n}} \mathrm{se} / \\
\mathrm{CL} 3-\mathrm{all}\end{array}$ & {$\left[\mathrm{wo}^{\mathrm{n}} \mathrm{se}\right]$} & 'all' \\
\hline$(8)$ & $\begin{array}{c}/ \mathrm{i}_{-\mathrm{a}}^{\mathrm{n}} \mathrm{gu} / \\
\text { CL4-mine }\end{array}$ & {$\left[j a^{n} \mathrm{gu}\right]$} & 'mine' & $(15)$ & $\begin{array}{c}\text { /i-a }{ }^{\mathrm{g}} \mathrm{gu} / \\
\text { CL4-mine }\end{array}$ & {$\left[\mathrm{ja}^{\mathrm{n}} \mathrm{gu}\right]$} & 'mine' \\
\hline (9) & $\begin{array}{l}\text { /i-ake/ } \\
\text { CL4-his }\end{array}$ & [jake] & 'his' & (16) & $\begin{array}{l}\text { /i-ake/ } \\
\text { CL4-his }\end{array}$ & [jake] & 'his' \\
\hline (10) & $\begin{array}{c}\text { i-ose/ } \\
\text { CL9-whole }\end{array}$ & [jose] & 'whole' & (17) & $\begin{array}{l}\text { /i-o }{ }^{\mathrm{n}} \mathrm{se} / \\
\text { CL9-all }\end{array}$ & {$\left[\mathrm{jo}^{\mathrm{n}} \mathrm{se}\right]$} & 'all' \\
\hline (11) & $\begin{array}{c}\text { /i-edu/ } \\
\text { CL9-ours }\end{array}$ & [jedu] & 'ours' & (18) & $\begin{array}{c}\text { /i-eka/ } \\
\text { CL9-only }\end{array}$ & [jeka] & 'only' \\
\hline
\end{tabular}


Glide formation is also evident in verbs, within the Inflectional Stem bearing affixes like subject and TAM, as shown in Table 2:

Table 2. Glide formation in verbs

\begin{tabular}{|c|c|c|c|c|c|c|c|}
\hline \multicolumn{4}{|c|}{ CiNsenga } & \multicolumn{4}{|c|}{ ChiShona } \\
\hline & Underlying & Surface & Meaning & & Underlying & Surface & Meaning \\
\hline (19) & $\begin{array}{l}\text { /u-a-lil-a/ } \\
\text { 1SM-PST- } \\
\text { cry-Fv }\end{array}$ & [walila] & $\begin{array}{c}\text { 'he/she } \\
\text { cried' } \\
\text { (hodiernal) }\end{array}$ & (23) & $\begin{array}{c}\text { /u-a-djg-a/ } \\
\text { 3SM-PST- } \\
\text { eat-FV }\end{array}$ & [wadgga] & $\begin{array}{l}\text { 'you } \\
\text { ate' }\end{array}$ \\
\hline (20) & $\begin{array}{l}\text { /i-a-fom-a/ } \\
\text { 9SM-PST- } \\
\text { sweat-FV }\end{array}$ & [jafoma] & $\begin{array}{c}\text { 'it } \\
\text { sweated' } \\
\text { (hodiernal) }\end{array}$ & (24) & $\begin{array}{c}\text { /u-a-e }{ }^{\mathrm{n}} \mathrm{d}-\mathrm{a} / \\
\text { 3SM-PST- } \\
\text { go-FV }\end{array}$ & {$\left[\text { waje }^{\mathrm{n}} \mathrm{da}\right]^{4}$} & $\begin{array}{l}\text { 'you } \\
\text { went' }\end{array}$ \\
\hline (21) & $\begin{array}{c}\text { /u-e- }{ }^{\mathrm{n}} \mathrm{ze} \\
\text { mu-tu/ } \\
\text { 3SM-PST- } \\
\text { be CL3- } \\
\text { head }\end{array}$ & $\begin{array}{l}{\left[\mathrm{we}^{\mathrm{n}} \mathrm{ze}\right.} \\
\text { mutu] }\end{array}$ & $\begin{array}{l}\text { 'it was a } \\
\text { head' }\end{array}$ & $(25)$ & $\begin{array}{c}\text { /i-a-dzg-a/ } \\
\text { 9SM-PST- } \\
\text { eat-FV }\end{array}$ & [jadzga] & 'it ate' \\
\hline (22) & $\begin{array}{c}\text { /i-e- }{ }^{\mathrm{n}} \mathrm{ze} \text { mi- } \\
\text { tu/ } \\
\text { 4SM-PST- } \\
\text { be CL4- } \\
\text { head }\end{array}$ & $\begin{array}{l}{\left[\mathrm{je}^{\mathrm{n}} \mathrm{ze}\right.} \\
\text { mitu] }\end{array}$ & $\begin{array}{c}\text { 'they were } \\
\text { heads' }\end{array}$ & (26) & $\begin{array}{c}/ \mathrm{i}-\mathrm{a}-\mathrm{e}^{\mathrm{n}} \mathrm{d}-\mathrm{a} / \\
\text { 9SM-PST- } \\
\text { go-FV }\end{array}$ & {$\left[\mathrm{jaje}^{\mathrm{n}} \mathrm{da}\right]$} & 'it went' \\
\hline
\end{tabular}

What has been shown here is that glide formation in ciNsenga and chiShona is triggered when the $\mathrm{V}_{1}(/ \mathrm{u} /$ or $/ \mathrm{i} /)$ occurs without a preceding consonant. When /a/ is in the initial position, glide formation is blocked and elision occurs. In both chiShona and ciNsenga, there are no right contexts to test whether /e/ and /o/ would participate in glide formation. However, cases in which prevocalic mid vowels undergo glide formation are reported in Shimakonde (Liphola 2001:135) and Ivie (Masagbor 1989:87), as shown in Tables 3 and 4, respectively:

Table 3. Prevocalic mid vowels undergoing glide formation in Shimakonde

\begin{tabular}{|l|l|l|l|}
\hline & \multicolumn{1}{|c|}{ Underlying } & \multicolumn{1}{c|}{ Surface } & \multicolumn{1}{c|}{ Meaning } \\
\hline$(27)$ & /lideebe \# oomba/ & [lideebjoomba] & 'the tin, play it' \\
\hline$(28)$ & /litatele \# eepa/ & [litateljeepa $]$ & 'the cucumber, harvest it' \\
\hline$(29)$ & $/$ lidoodo \# aanda/ & [lidoodwaanda] & 'the leg, make tattoo on it' \\
\hline$(30)$ & $/$ lidioodo \# ooma/ & [lidoodwooma $]$ & 'the led, pierce it' \\
\hline
\end{tabular}

Table 4. Prevocalic mid vowels undergoing glide formation in Ivie

\begin{tabular}{|l|l|l|l|}
\hline & Underlying & \multicolumn{1}{c|}{ Surface } & \multicolumn{1}{c|}{ Meaning } \\
\hline$(31)$ & /to \# oxe/ & [twoxe] & 'tell a story' \\
\hline$(32)$ & $/$ do \# ode/ & [dwode] & 'weave cloth' \\
\hline$(33)$ & $/$ ode \# e/ & [odje] & 'your cloth' \\
\hline
\end{tabular}

\footnotetext{
${ }^{4}$ In (24) and (26), glide epenthesis in the form of spreading is used to resolve the hiatus between the tense marker and the verb stem. This is the domain for spreading in chiShona, while resyllabification in the form of glide formation is used within the Inflectional Stem. Spreading across the Prosodic Stem in chiShona is discussed in $\S 5$.
} 
In (27) through (33), /e o/ undergo glide formation across word boundaries. Fortune (1955) and Miti (2001) present data which show that chiShona and ciNsenga do not resolve hiatus across word boundaries. The changes in (5) through (26) are schematised in (34).

$$
\begin{aligned}
& \text { Gliding of high vowels } \\
& \begin{aligned}
\text { a. } / \mathrm{u}+\mathrm{a} / \rightarrow & {[\mathrm{wa}] } \\
\text { b. } / \mathrm{u}+\mathrm{e} / \rightarrow & {[\mathrm{we}] } \\
\text { c. } / \mathrm{u}+\mathrm{o} / \rightarrow & {[\mathrm{wo}] } \\
\text { d. } / \mathrm{i}+\mathrm{a} / \rightarrow & {[\mathrm{ja}] } \\
\text { e. } / \mathrm{i}+\mathrm{e} / \rightarrow & {[\mathrm{je}] } \\
\text { f. } / \mathrm{i}+\mathrm{o} / \rightarrow & {[\mathrm{jo}] }
\end{aligned}
\end{aligned}
$$

Reordering the vowels has a different effect. For example, the reverse sequences of $/ \mathrm{i}+\mathrm{a} / \mathrm{and}$ $/ \mathrm{u}+\mathrm{a} /$ are subject to coalescence in chiShona: $[\mathrm{a}+\mathrm{u}] \rightarrow[\mathrm{o}],[\mathrm{a}+\mathrm{i}] \rightarrow[\mathrm{e}]$ (see Harford 1997, Mudzingwa 2010, Kadenge 2010 $)^{5}$. As mentioned earlier, coalescence operates in chiShona and not in ciNsenga. In both languages, glide formation does not result in compensatory lengthening which ultimately results in mora loss. Every potential $\mathrm{V}_{1} . \mathrm{V}_{2}$ sequence violates the markedness constraint that penalises onsetless syllables, namely:

\section{ONSET \\ Syllables must have onsets}

(Ito 1989:223)

This markedness constraint is ranked above the faithfulness constraint that militates against mora loss (defined in (36)), thus allowing glide formation to repair hiatus by converting $\mathrm{V}_{1}$ to a glide (Rosenthall 1994, 1997; Mudzingwa and Kadenge 2011).

\section{$\operatorname{MAX}-\mathrm{IO}(\mu)$}

Every mora in the Input has a correspondent in the Output

(Rosenthall 1997:147)

As mentioned earlier, in both ciNsenga and chiShona, the loss of a mora in glide formation does not trigger compensatory lengthening. This is a common characteristic of languages that do not have contrastive vowel length (Odden and Odden 1999:423). In languages with contrastive vowel length, such as Luganda, hiatus resolution of this nature typically results in compensatory lengthening, as shown in Table 5 below (data from Katamba 1989:171):

Table 5. Hiatus resolution resulting in vowel lengthening in Luganda

\begin{tabular}{|c|c|c|c|}
\hline & Underlying & Surface & Meaning \\
\hline$(37)$ & /mu-a-lab-a/ & {$\left[\mathrm{m}^{\mathrm{w}}\right.$ a:laba $]$} & 'you saw' \\
\hline$(38)$ & $/$ li-ato/ & {$\left[\mathrm{l}^{\mathrm{j} a}: \mathrm{to}\right]$} & 'boat, canoe' \\
\hline$(39)$ & $/$ ba-a-lab-a/ & {$[$ ba:laba] } & 'they saw' \\
\hline$(40)$ & $/$ ba-e-lab-a/ & {$[$ be:laba $]$} & 'they see themselves' \\
\hline
\end{tabular}

\footnotetext{
${ }^{5}$ Kadenge (2010:9) provides the following examples of chiShona words in which coalescence occurs:

$/ \mathrm{a}+\mathrm{u} / \rightarrow[\mathrm{o}]: / \mathrm{h} \mathrm{a}+\mathrm{uju} / \rightarrow$ [hoju] 'this one' and /ḥa + ujo/ $\rightarrow$ [ḥojo] 'that one'; $/ \mathrm{a}+\mathrm{i} / \rightarrow[\mathrm{e}]: /$ ha $+\mathrm{itfi} / \rightarrow[$ ḥetfi] 'this one' and $/ \mathrm{a}+\mathrm{idu} / \rightarrow$ [edu] 'ours'.
} 
The markedness constraint that militates against long vowels which result from compensatory lengthening is undominated in both ciNsenga and chiShona, and is defined in (41):

$$
\begin{aligned}
& * \mathrm{~V} \text { : } \\
& \text { No long vowels }
\end{aligned}
$$

(Rosenthall 1997:147)

Deletion is less optimal than glide formation, and the faithfulness constraint that prohibits segment deletion is defined in (42):

\author{
MAX-IO(RT) \\ Every root node in the Input has a correspondent in the Output
}

(Mudzingwa 2010)

Tableau 1 below shows a contrast between an optimal glide-containing candidate and a faithful candidate that preserves hiatus. In addition, this tableau provides a parallel evaluation of a glidecontaining candidate and those that delete one of the vowels.

Tableau 1. Glide formation in ciNsenga and chiShona

\begin{tabular}{|c|c|c|c|c|}
\hline$/ \mathrm{u}_{1}-\mathrm{a}_{2} \mathrm{ko} /$ & ONSET & $* \mathrm{~V}:$ & MAX-IO(RT) & $\operatorname{MAX}-\mathrm{IO}(\mu)$ \\
\hline a. $\left[\mathrm{u}_{1} \cdot \mathrm{a}_{2} \cdot \mathrm{ko}\right]$ & $* !$ & & & \\
\hline b.[wa $2 . k o]$ & & $* !$ & & \\
\hline c. $\left[a_{2} . k o\right]$ & & & $* !$ & $*$ \\
\hline d.[u u $\left._{1 . k o}\right]$ & & & $* !$ & $*$ \\
\hline e.[wa $2 . k o]$ & & & & $*$ \\
\hline
\end{tabular}

ONSET, *V: >> MAX-IO(RT) $>>$ MAX-IO $(\mu)$

The faithful parse (a) fatally violates the markedness constraint ONSET. It satisfies all other constraints, but since the ONSET constraint is high-ranked, this candidate is eliminated. Candidate (b), which satisfies the ONSET constraint by gliding $V_{1}$ and lengthening $V_{2}$ in compensation for the lost mora, is not optimal because it violates the high-ranked markedness constraint $* \mathrm{~V}$ : . Candidates (c) and (d) avoid the violation of ONSET by deleting $\mathrm{V}_{1}$ and $\mathrm{V}_{2}$, respectively. These candidates are less optimal than candidate (e) because they incur simultaneous violations of MAX-IO(RT) and MAX-IO $(\mu)$. Thus they are less optimal than candidate (e) which violates the faithfulness constraint $\operatorname{MAX}-\mathrm{IO}(\mu)$ only. Therefore, (e) is the optimal candidate; its violation of $\operatorname{MAX}-\operatorname{IO}(\mu)$ is not consequential as the constraint is lowranked, suggesting that segment deletion is less optimal than glide formation in ciNsenga and chiShona. The formal analysis provided for turning /u/ into a glide [w] can be applied mutatis mutandis for gliding /i/ to [j].

Although glide formation is the primary strategy for resolving hiatus, it is not always used in ciNsenga and chiShona. When glide formation is blocked due to a syllable-structure constraint that bans complex onsets, secondary articulation is triggered. The following section presents data illustrating morphosyntactic and phonological contexts in which secondary articulation the second best strategy - operates in ciNsenga and chiShona. 


\subsection{Secondary articulation}

Another common strategy for resolving vowel hiatus in ciNsenga and chiShona is secondary articulation (labialisation), which occurs when $\mathrm{V}_{1}$ is $/ \mathrm{u} /$ and is preceded by an onset. When $\mathrm{V}_{1}$ is $/ \mathrm{i} /$ and is preceded by a consonant, secondary articulation is blocked because it would result in palatalised consonants which are not permissible in both languages. Glide formation would result in complex onsets which are also banned in both ciNsenga and chiShona. As a result, elision occurs. Secondary articulation occurs in nouns and possessive pronouns, as shown in Table 6 below:

Table 6. Secondary articulation in nouns and possessive pronouns

\begin{tabular}{|c|c|c|c|c|c|c|c|}
\hline \multicolumn{4}{|c|}{ ChiShona } & \multicolumn{4}{|c|}{ CiNsenga } \\
\hline & Underlying & Surface & Meaning & & Underlying & Surface & Meaning \\
\hline (43) & $\begin{array}{l}\text { /mu-ana/ } \\
\text { CL1-child }\end{array}$ & [mªna] & 'child' & (47) & $\begin{array}{c}/ \mathrm{tu}-\mathrm{a}^{\mathrm{p}} \mathrm{gu} / \\
\text { CL13-mine }\end{array}$ & {$\left[\mathrm{t}^{\mathrm{w}} \mathrm{a}^{\mathrm{n}} \mathrm{gu}\right]$} & 'mine' \\
\hline (44) & $\begin{array}{l}\text { /ku-ake/ } \\
\text { CL15-his }\end{array}$ & {$\left[\mathrm{k}^{\mathrm{w}}\right.$ ake $]$} & 'his' & (48) & $\begin{array}{l}/ \mathrm{ku}-\mathrm{a}^{\mathrm{p}} \mathrm{gu} / \\
\text { CL15-mine }\end{array}$ & {$\left[\mathrm{k}^{\mathrm{w}} \mathrm{a}^{\mathrm{p}} \mathrm{gu}\right]$} & 'mine' \\
\hline (45) & $\begin{array}{l}\text { /mu-eni/ } \\
\text { CL1-visitor }\end{array}$ & {$\left[\mathrm{m}^{\mathrm{w}} \mathrm{eni}\right]$} & 'visitor' & (49) & $\begin{array}{c}\text { /tu-eka/ } \\
\text { CL13-only }\end{array}$ & {$\left[\mathrm{t}^{\mathrm{w}} \mathrm{eka}\right]$} & 'only' \\
\hline (46) & $\begin{array}{c}\text { ru-edu/ } \\
\text { CL11-ours }\end{array}$ & {$\left[\mathrm{r}^{\mathrm{w}} \mathrm{edu}\right]$} & 'ours' & & & & \\
\hline
\end{tabular}

In both ciNsenga and chiShona, secondary articulation is also productive in verbs within the Inflectional Stem, as shown in Table 7 below:

Table 7. Secondary articulation in verbs

\begin{tabular}{|c|c|c|c|c|c|c|c|}
\hline \multicolumn{4}{|c|}{ CiNsenga } & \multicolumn{4}{|c|}{ ChiShona } \\
\hline & Underlying & Surface & Meaning & & Underlying & Surface & Meaning \\
\hline$(50)$ & $\begin{array}{c}\text { /mu-a-wel-a/ } \\
\text { SM-PST- } \\
\text { come-FV }\end{array}$ & [mªwela] & $\begin{array}{l}\text { 'you came' } \\
\text { (hodiernal) }\end{array}$ & $(52)$ & $\begin{array}{c}\text { /tu-a-i }{ }^{\mathrm{m}} \mathrm{b}-\mathrm{a} / \\
\text { 13SM-PST- } \\
\text { sing-FV }\end{array}$ & {$\left[\mathrm{t}^{\mathrm{w}} \mathrm{aji}^{\mathrm{m}} \mathrm{ba}\right]$} & $\begin{array}{l}\text { 'they } \\
\text { sang' }\end{array}$ \\
\hline$(51)$ & $\begin{array}{c}\text { /mu-e- } \\
\mathrm{n}_{\text {zemu-a- }} \\
\text { tini-lal-e/ } \\
\text { SM-PST-be } \\
\text { SM-PST-say } \\
\text { SM-sleep-FV }\end{array}$ & $\begin{array}{l}{\left[\mathrm{m}^{\mathrm{w}} \mathrm{e}^{\mathrm{n}} \mathrm{zem}^{\mathrm{w}} \text { ati }\right.} \\
\text { nilale }]\end{array}$ & $\begin{array}{l}\text { 'you said I } \\
\text { should } \\
\text { sleep' } \\
\text { (hodiernal) }\end{array}$ & (53) & $\begin{array}{c}\text { /ru-a-dzg-a/ } \\
11 \mathrm{SM}-\mathrm{PST}- \\
\text { eat-FV }\end{array}$ & [rwadzga] & 'it ate' \\
\hline & & & & $(54)$ & $\begin{array}{c}\text { /ku-a-ta }{ }^{\mathrm{m}} \mathrm{b}- \\
\mathrm{w}-\mathrm{a} / \\
\text { 15INF-PST- } \\
\text { dance-PASS- } \\
\text { FV }\end{array}$ & {$\left[\mathrm{k}^{\mathrm{w}} \mathrm{ata}^{\mathrm{m}} \mathrm{b}^{\mathrm{w}} \mathrm{a}\right]$} & $\begin{array}{c}\text { 'they } \\
\text { danced' }\end{array}$ \\
\hline
\end{tabular}

When $\mathrm{V}_{1}$ is $/ \mathrm{u} /$ and is preceded by a consonant, glide formation, which would result in a $\mathrm{C}^{\mathrm{w}}$ cluster, is blocked by a markedness constraint that prohibits complex onsets. Consequently, secondary articulation is triggered. Complex onsets are not allowed in ciNsenga and chiShona. The constraint that bans complex onsets is defined in (55): 


\author{
*COMPLEX \\ Complex onsets are prohibited
}

(McCarthy 2008:261)

In ciNsenga and chiShona, this constraint is undominated. In both languages, secondary articulation only occurs with compatible consonants, i.e. consonants that allow labialisation $\left(\mathrm{C}^{\mathrm{w}} \mathrm{s}\right)$.

Tableau 2. Secondary articulation in ciNsenga and chiShona

ONSET, *V:, *COMPLEX $>>$ MAX-IO(RT) $>>$ MAX-IO $(\mu)$

\begin{tabular}{|c|c|c|c|c|c|}
\hline$/ \mathrm{tu}_{1}-\mathrm{a}_{2}{ }^{\mathrm{n}} \mathrm{gu} /$ & ONSET & $* \mathrm{~V}:$ & *COMPLEX & MAX-IO(RT) & MAX-IO $(\mu)$ \\
\hline a. $\left[\mathrm{tu}_{1} \cdot \mathrm{a}_{2} \cdot{ }^{\mathrm{y}} \mathrm{gu}\right]$ & $* !$ & & & & \\
\hline b. $\left[\mathrm{twa}_{2} \cdot{ }^{\mathrm{y}} \mathrm{gu}\right]$ & & & $* !$ & & * \\
\hline c. $\left[\mathrm{t}^{\mathrm{w}} \mathrm{a}: 2 .{ }^{\mathrm{g}} \mathrm{gu}\right]$ & & $* !$ & & * & \\
\hline d. $\left[\mathrm{t}^{\mathrm{w}} \mathrm{a}_{2} \cdot{ }^{\mathrm{n}} \mathrm{gu}\right]$ & & & & * & * \\
\hline
\end{tabular}

In this tableau, candidate (a), which is fully faithful and does not resolve hiatus, violates the undominated markedness constraint ONSET. Candidate (b) satisfies ONSET by stripping the moraicity of $\mathrm{V}_{1}$, thereby creating a consonant cluster [tw]. As a result, it fatally violates the undominated syllable-structure markedness constraint *COMPLEX. This constraint effectively blocks glide formation when $V_{1}$ is preceded by a consonant. Candidate (c) satisfies both ONSET and *COMPLEX by turning $\mathrm{V}_{1}$ into secondary articulation. It is, however, suboptimal because it lengthens $\mathrm{V}_{2}$ in compensation for the lost mora. Consequently, it violates the high-ranked markedness constraint $* \mathrm{~V}$. . Candidate (d) satisfies all the undominated constraints and, although it violates the low-ranked faithfulness constraints $\operatorname{MAX}-\mathrm{IO}(\mathrm{RT})$ and $\operatorname{MAX}-\mathrm{IO}(\mu)$, it is the winner.

As mentioned earlier, when glide formation and secondary articulation are blocked, elision is triggered. The following section discusses the phonological and morphosyntactic contexts in which vowel elision occurs in chiShona and ciNsenga.

\title{
4.3 Vowel elision
}

Vowel elision is the least preferred repair strategy because it dispenses with all the features of $V_{1}$ (Rosenthall 1997, Mudzingwa 2010, Simango and Kadenge 2014). There are phonotactic and phonological factors that trigger elision and, in both languages, this process operates in similar phonological and morphological contexts. Vowel elision occurs primarily in possessive pronouns, but it also occurs in nouns and verbs, as illustrated in Table 8. Possessive pronouns consist of a VCV stem to which a noun-class prefix, typically consisting of $\mathrm{CV}$, is attached. This attachment invariably results in vowel hiatus which is repaired through elision. 
Table 8. Vowel elision in nouns and possessive pronouns

\begin{tabular}{|c|c|c|c|c|c|c|c|}
\hline \multicolumn{4}{|c|}{ CiNsenga } & \multicolumn{4}{|c|}{ ChiShona } \\
\hline & Underlying & Surface & Meaning & & Underlying & Surface & Meaning \\
\hline$(56)$ & $\begin{array}{l}/ \mathrm{t} \mathrm{fi}-\mathrm{a}^{\mathrm{p}} \mathrm{gu} / \\
\text { CL7-mine }\end{array}$ & {$\left[\mathfrak{g a}^{\mathrm{n}} \mathrm{gu}\right]$} & 'mine' & (69) & $\begin{array}{l}\text { /ri-a } \mathrm{a}^{\mathrm{n}} \mathrm{gu} / \\
\text { CL5-mine }\end{array}$ & {$\left[\mathrm{ra}^{\mathrm{n}} \mathrm{gu}\right]$} & 'mine' \\
\hline$(57)$ & $\begin{array}{l}\text { /tyi-asu/ } \\
\text { CL7-our }\end{array}$ & [tasu] & 'ours' & (70) & $\begin{array}{l}\text { /ri-edu/ } \\
\text { CL5-our }\end{array}$ & [redu] & 'ours' \\
\hline$(58)$ & $\begin{array}{l}\text { /tyi-ake/ } \\
\text { CL7-her }\end{array}$ & [take] & 'hers' & (71) & $\begin{array}{l}\text { /zi- } \mathrm{a}^{\mathrm{n}} \mathrm{gu} / \\
\text { C̈̈8-mine }\end{array}$ & {$\left[\mathrm{za}^{\mathrm{n}} \mathrm{gu}\right]$} & 'mine' \\
\hline$(59)$ & $\begin{array}{l}/ \text { /i-a }{ }^{\mathrm{y}} \mathrm{gu} / \\
\text { CL5-mine }\end{array}$ & {$\left[1 \mathrm{a}^{\mathrm{n}} \mathrm{gu}\right]$} & 'mine' & (72) & $\begin{array}{l}\text { /ti-ake/ } \\
\text { CL7-his }\end{array}$ & [tgake] & 'mine' \\
\hline$(60)$ & $\begin{array}{l}\text { /li-asu/ } \\
\text { CL5-our }\end{array}$ & lasu] & 'ours' & (73) & $\begin{array}{l}\text { /tyi-oja/ } \\
\text { CL7-pubic } \\
\text { hair }\end{array}$ & [toja] & $\begin{array}{l}\text { 'pubic } \\
\text { hair' }\end{array}$ \\
\hline$(61)$ & $\begin{array}{l}\text { /li-ake/ } \\
\text { CL5-her }\end{array}$ & [lake] & 'hers' & (74) & $\begin{array}{c}\text { /zi-uru/ } \\
\text { CL } \ddot{8} \text {-ant hill }\end{array}$ & [zururu] & 'ant hills' \\
\hline$(62)$ & $\begin{array}{c}\text { /ka-ako/ } \\
\text { CL12-your }\end{array}$ & [kako] & 'yours' & $(75)$ & $\begin{array}{l}\text { /pa-ake/ } \\
\text { CL16-his }\end{array}$ & [pake] & 'his' \\
\hline (63) & $\begin{array}{l}\text { /ka-asu/ } \\
\text { CL12-our }\end{array}$ & {$[\mathrm{kasu}]$} & 'ours' & (76) & $\begin{array}{c}\text { /ka-avo/ } \\
\text { CL12-theirs }\end{array}$ & [kavo] & 'theirs' \\
\hline (64) & $\begin{array}{l}\text { /ka-awo/ } \\
\text { CL12-their }\end{array}$ & [kawo] & 'theirs' & (77) & $\begin{array}{l}\text { /mu-ojo/ } \\
\text { CL3-heart }\end{array}$ & [mojo] & 'heart' \\
\hline$(65)$ & $\begin{array}{l}\text { /tii-ola/ } \\
\text { CL7-bag }\end{array}$ & [tfola $]$ & 'bag' & (78) & $\begin{array}{c}/ \mathrm{mu}-\mathrm{o}^{\mathrm{n}} \mathrm{go} / \\
\text { CL3-bone } \\
\text { marrow }\end{array}$ & {$\left[\mathrm{mo}^{\mathrm{y}} \mathrm{go}\right]$} & $\begin{array}{c}\text { 'bone } \\
\text { marrow' }\end{array}$ \\
\hline$(66)$ & $\begin{array}{c}/ \mathrm{t} \text { ii-ulu/ } \\
\text { CL 7-anthill }\end{array}$ & [tgulu] & 'ant hill' & & & & \\
\hline$(67)$ & $\begin{array}{l}/ \text { tu-on } \mathrm{se} / \\
\text { CL13-all }\end{array}$ & {$\left[\mathrm{to}^{\mathrm{n}} \mathrm{se}\right]$} & 'all' & & & & \\
\hline$(68)$ & $\begin{array}{l}/ \mathrm{ku}-\mathrm{o}^{\mathrm{n}} \mathrm{se} / \\
\text { CL17-all }\end{array}$ & {$\left[\mathrm{ko}^{\mathrm{n}} \mathrm{se}\right]$} & 'all' & & & & \\
\hline
\end{tabular}

In the verbal domain, vowel elision occurs when two prefix vowels are juxtaposed, and when $\mathrm{V}_{1}$ is /i/ and is preceded by a consonant, as shown in Table 9 below:

Table 9. Vowel elision in verbs

\begin{tabular}{|c|c|c|c|c|c|c|c|}
\hline \multicolumn{4}{|c|}{ CiNsenga } & \multicolumn{4}{|c|}{ ChiShona } \\
\hline & Underlying & Surface & Meaning & & Underlying & Surface & Meaning \\
\hline (79) & $\begin{array}{c}\text { /si-u-ka-ni-timb-a/ } \\
\text { NEG-SM-FUT- } \\
\text { OM-beat-FV }\end{array}$ & [sukaniti $\left.{ }^{\mathrm{m}} \mathrm{ba}\right]$ & $\begin{array}{l}\text { 'you (sg) will } \\
\text { not beat me' }\end{array}$ & (82) & $\begin{array}{c}\text { /ti-a-djg-a/ } \\
\text { SM-PST-eat-Fv }\end{array}$ & [tadzga] & 'we ate' \\
\hline (80) & $\begin{array}{l}\text { /ni-a-fum-a/ } \\
\text { SM-PST-come } \\
\text { out-FV }\end{array}$ & [nafuma] & $\begin{array}{l}\text { 'I came out' } \\
\text { (hodiernal) }\end{array}$ & (83) & $\begin{array}{l}\text { /ndi-a-karar-a/ } \\
\text { SM-PST-sleep-FV }\end{array}$ & [" dakarara] & 'I slept' \\
\hline$(81)$ & $\begin{array}{c}\text { ti-e-lal-a/ } \\
\text { SM-PST-sleep-FV }\end{array}$ & [telala] & $\begin{array}{c}\text { 'we slept' } \\
\text { (pre-hodiernal) }\end{array}$ & (84) & $\begin{array}{l}\text { /va-a-dsg-a/ } \\
\text { SM-PsT-eat-Fv }\end{array}$ & [vad3g-a] & 'they ate' \\
\hline
\end{tabular}


There are three main phonological environments in which vowels are elided in ciNsenga and chiShona. First, elision occurs when $\mathrm{V}_{1}$ is $/ \mathrm{i} /$ and is preceded by a consonant. In these languages, palatalised consonants are not allowed, which suggests that post-consonantal $\mathrm{V}_{1} / \mathrm{i} /$ cannot result in a palatalised consonant. This sets ciNsenga and chiShona apart from other Bantu languages such as Luganda (Katamba 1989) and Nambya (Kadenge 2008, Mudzingwa and Kadenge 2011) which have palatalised consonants in their consonant inventories ${ }^{6}$. In these languages, palatalisation is used to resolve hiatus.

The second phonological environment in which elision occurs is when $V_{1}$ is /a/ with or without a preceding consonant. This suggests that neither low glides nor pharyngeal consonants are acceptable in ciNsenga and chiShona. In terms of directionality in vowel elision, both languages are $\mathrm{V}_{1}$-deleting grammars. Cross-linguistically, $\mathrm{V}_{1}$ elision is far more common than the elision of $\mathrm{V}_{2}$ (see Casali 1997, 1998, 2011; Mudzingwa 2010, 2013; Mudzingwa and Kadenge 2011; Simango and Kadenge 2014).

The third phonological environment involves / $\mathrm{u} /$ being elided when preceded by a consonant and followed by a labial vowel. The syllable structure, segmental, morphosyntactic and phonotactic prohibitions that trigger elision are captured by the markedness constraints in (85-89):

${ }^{*} \mathrm{C}^{\mathrm{j}}$
Palatalised consonants are prohibited

(Sibanda 2009:48, Mudzingwa 2010:19)

(86) ANCHOR L

Any root node at the left edge of a morpheme in the Input has a correspondent root node in the Output

(Casali 1998)

*LOW-GLIDE

Low glides are prohibited (or glides must be [+high])

(Casali 1997:516)

$* \mathrm{C}^{\varsigma}$

Pharyngealised consonants are prohibited

(Mudzingwa 2010)

$*\left[\mathrm{C}^{\mathrm{W}} \mathrm{V}_{\mathrm{LAB}}\right]$

A sequence of a labialised consonant and a labial (round) vowel is prohibited

Tableau 3 illustrates how the ranking of these constraints results in elision of /i/ in ciNsenga and chiShona.

\footnotetext{
${ }^{6}$ In (38) we present an example showing the occurrence of palatalisation in Luganda. Mudzingwa and Kadenge (2011:206) provide examples in which palatalisation occurs in Nambya, like /mi-ojo/ $\rightarrow$ [m'ojo] 'hearts' (CL4), and $/ \mathrm{li}-\mathrm{a}^{\mathrm{p}} \mathrm{gu} / \rightarrow\left[\mathrm{l}^{\mathrm{j}} \mathrm{a}^{\mathrm{p}} \mathrm{gu}\right]$ 'mine' (CL5). The difference between these two languages is that Luganda allows compensatory lengthening while Nambya does not. Thus, Nambya patterns with ciNsenga and chiShona in prohibiting compensatory lengthening.

${ }^{7}$ A reviewer proposed that we use an OCP-driven constraint to account for the elision of /i/ when preceded by alveopalatal consonants. The chiShona examples in (69), (70), (71) and (74), and the ciNsenga examples in (79), (80) and (81) show that /i/ elision also occurs in the context of non-palatal consonants, suggesting that what is banned in these languages are palatalised consonants in general and not just the palatalisation of palatal consonants. This is not surprising as ciNsenga and chiShona do not have such segments in their consonant inventories.
} 
Tableau 3. /i/ elision in chiShona and ciNsenga

ONSET, *COMPLEX, ANCHOR L,${ }^{*} \mathrm{C}^{\mathrm{j}}>>$ MAX-IO $(\mathrm{RT})>>$ MAX-IO $(\mu)$

\begin{tabular}{|c|c|c|c|c|c|c|}
\hline$/ \mathrm{tg} \mathrm{i}_{1}-\mathrm{a}_{2}{ }^{\mathrm{p}} \mathrm{gu} /$ & ONSET & *COMPLEX & ANCHOR L & ${ }^{*} \mathrm{C}^{\mathrm{j}}$ & MAX-IO(RT) & MAX-IO $(\mu)$ \\
\hline a. $\left[\mathrm{ffi}_{1} \cdot \mathrm{a}_{2} \cdot{ }^{\mathrm{g}} \mathrm{gu}\right]$ & $* !$ & I & " & & & \\
\hline b. $\left[\mathrm{tg}_{1},{ }^{\mathrm{y}} \mathrm{gu}\right]$ & & 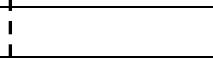 & $* !$ & & $*$ & $*$ \\
\hline c. $\left[\mathrm{tgja}_{2} \cdot{ }^{\mathrm{n}} \mathrm{gu}\right]$ & & $* !$ & 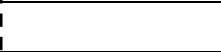 & & & $*$ \\
\hline d. $\left[\mathrm{tg}^{\mathrm{j}} \mathrm{a}_{2} \cdot{ }^{\mathrm{j}} \mathrm{gu}\right]$ & & i & 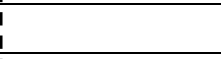 & $* !$ & $*$ & $*$ \\
\hline$\leftrightarrow \mathrm{e} .\left[\mathrm{ta}{ }_{2}{ }^{\mathrm{y}} \mathrm{gu}\right]$ & & 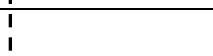 & 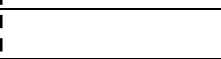 & & * & $*$ \\
\hline
\end{tabular}

In this tableau, candidate (a) with vowel hiatus crucially violates ONSET and is thus eliminated. Candidate (b), which deletes $\mathrm{V}_{2}$, is eliminated by ANCHOR L, the constraint which effectively blocks the elision of $\mathrm{V}_{2}$. Candidate (c) satisfies ONSET through glide formation but then fatally violates the high-ranked constraint *COMPLEX. Candidate (d) uses secondary articulation to avoid vocalic hiatus and complex onsets but it fatally violates ${ }^{*} \mathrm{C}^{\mathrm{j}}$, the segmental markedness constraint that bans palatalised consonants. The optimal candidate is thus (e), with $\mathrm{V}_{1}$ elided, which only violates lower-ranked constraints. The elision of /a/ without a preceding consonant is formalised in Tableau 4 below:

Tableau 4. Elision involving /a/ without a preceding consonant in ciNsenga and chiShona

ONSET, *LOW-GLIDE $>>$ MAX-IO(RT) $>>$ MAX-IO $(\mu)$

\begin{tabular}{|c|c|c|c|c|}
\hline$/ \mathrm{a}_{1}-\mathrm{a}_{2} \mathrm{ke} /$ & ONSET & *LOW-GLIDE & MAX-IO(RT) & MAX-IO $(\mu)$ \\
\hline a.[a1.a2.ke] & $* !$ & 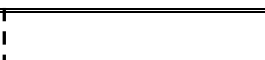 & & \\
\hline b. [@a $2 . k e]$ & & $* !$ & & * \\
\hline c.[a $2 . \mathrm{ke}]$ & & 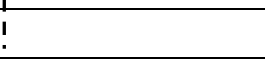 & $*$ & $*$ \\
\hline
\end{tabular}

In Tableau 4, the candidate with heterosyllabic vowel sequences, (a), incurs a fatal violation of the markedness constraint ONSET - which militates against onsetless syllables - while satisfying all others. Glide formation in (b) is suboptimal as it fatally incurs a violation of the segmental markedness constraint * LOW-GLIDE which bans low glides. The optimal candidate (c) satisfies all the high-ranked constraints but violates the low-ranked constraints MAX-IO(RT) and MAX$\mathrm{IO}(\mu)$ because it deletes $\mathrm{V}_{1} / \mathrm{a} /$. Just like low glides, pharyngealised consonants are prohibited in ciNsenga; the segmental markedness constraint that militates against pharyngealised consonants is defined in (88) and its effectiveness is shown in Tableau 5 below:

Tableau 5. Elision involving post consonantal /a/ in chiShona and ciNsenga

ONSET, ${ }^{*}$ COMPLEX, ${ }^{*} \mathrm{C}^{\uparrow}>>$ MAX-IO $(\mathrm{RT})>>$ MAX-IO $(\mu)$

\begin{tabular}{|c|c|c|c|c|c|}
\hline$/ \mathrm{ka}_{1}-\mathrm{a}_{2} \mathrm{ke} /$ & ONSET & *COMPLEX & ${ }^{*} \mathrm{C}^{\mathrm{C}}$ & MAX-IO(RT) & MAX-IO $(\mu)$ \\
\hline 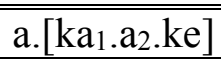 & $* !$ & I & 1 & & \\
\hline b. [kfa $2 . k e]$ & & $* !$ & 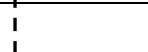 & & $*$ \\
\hline c. $\left[k^{\mathrm{C}} \mathrm{a}_{2} \cdot \mathrm{ke}\right]$ & & 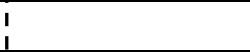 & $* !$ & * & $*$ \\
\hline d.[ka2.ke] & & i & 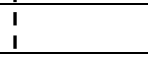 & $*$ & $*$ \\
\hline
\end{tabular}

Candidate (a) fatally violates ONSET because its $\mathrm{V}_{2}$ is onsetless. Candidate (b), which resolves hiatus through glide formation, violates the high-ranking markedness constraint *COMPLEX. Candidate (c) avoids vocalic hiatus and complex onsets through secondary articulation. It is however, less harmonic than candidate (d) because it creates a banned segment type - a 
pharyngealised plosive $\left[\mathrm{k}^{\varsigma}\right]$. It is thus eliminated by ${ }^{*} \mathrm{C}^{\mathrm{s}}$. Candidate $(\mathrm{d})$, which deletes $\mathrm{V}_{1} / \mathrm{a} /$, is the optimal candidate.

Examples (67), (68), (77) and (78) show that sequences of labialised consonants and labial vowels are prohibited in both chiShona and ciNsenga. The Obligatory Contour Principle (OCP)-driven constraint that militates against such segment sequences is defined in (89) and its effectiveness is shown in Tableau 6 below:

Tableau 6. /u/ elision in chiShona and ciNsenga

ONSET, *COMPLEX, ANCHOR L, *[C $\left.\mathrm{C}^{\mathrm{W}} \mathrm{V}_{\mathrm{LAB}}\right]>>\mathrm{MAX}-\mathrm{IO}(\mathrm{RT})>>\mathrm{MAX}-\mathrm{IO}(\mu)$

\begin{tabular}{|c|c|c|c|c|c|}
\hline$/ \mathrm{mu}_{1}-\mathrm{O}_{2} \mathrm{jo} /$ & $\begin{array}{l:l}\text { ONSET } & * \text { COMPLEX } \\
\end{array}$ & ANCHOR L & $*\left[\mathrm{C}^{\mathrm{W}} \mathrm{V}_{\mathrm{LAB}}\right]$ & MAX-IO(RT) & MAX-IO( $(\mu)$ \\
\hline a. $\left[\mathrm{mu}_{\left.1 . \mathrm{O}_{2} . \mathrm{jo}\right]}\right.$ & $* !$ & 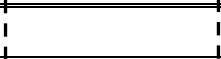 & & & \\
\hline b. $\left[\mathrm{mu}_{1 . j \mathrm{o}}\right]$ & 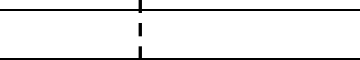 & $* !$ & & * & $*$ \\
\hline c. $\left[\mathrm{mWO}_{2 . j \mathrm{jo}}\right]$ & $* !$ & $\begin{array}{l}1 \\
\vdots \\
1\end{array}$ & 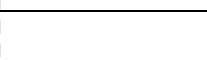 & & * \\
\hline d. $\left[\mathrm{m}^{\mathrm{w}} \mathrm{O}_{2} \cdot{ }^{\mathrm{y}} \mathrm{gu}\right]$ & 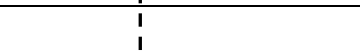 & $\begin{array}{l}t_{1} \\
\vdots\end{array}$ & $* !$ & $*$ & $*$ \\
\hline e. $\left[\mathrm{mo}_{2} . \mathrm{jo}\right]$ & i & $\begin{array}{l}\vdots \\
\vdots \\
\end{array}$ & 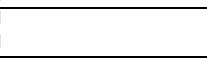 & $*$ & $*$ \\
\hline
\end{tabular}

Candidates (a), (b) and (c) are disqualified for violating the high-ranking constraints ONSET, ANCHOR L and *COMPLEX, respectively. Candidate (d), which employs secondary articulation, fatally violates the $\mathrm{OCP}$-driven constraint $*\left[\mathrm{C}^{\mathrm{W}} \mathrm{V}_{\mathrm{LAB}}\right]$. This constraint effectively bans sequences of labialised consonants and a labial vowel. Candidate (e), which elides $V_{1}$, is the optimal candidate. The blocking of glide formation and secondary articulation triggers elision.

Our observations thus far show that ciNsenga and chiShona are similar with respect to the strategies utilised in resolving vowel hiatus in nominals and the Inflectional Stem of verbs. Repair strategies employed in these morphosyntactic domains are glide formation, secondary articulation and elision. This, however, is where the similarities between the two languages end. Across the Prosodic Stem boundary, the two languages exhibit contrasting behaviour and it is to this that we now turn.

\section{Vowel hiatus across the Prosodic Stem boundary}

Across the Prosodic Stem boundary of the verb, vowel hiatus is tolerated in ciNsenga (Simango and Kadenge 2014) but has to be resolved in chiShona (Mudzingwa 2010, 2013). Examples from ciNsenga are presented in Table 10: 
Table 10. Vowel hiatus across the Prosodic Stem boundary in ciNsenga

\begin{tabular}{|c|c|c|c|}
\hline & Underlying & Surface & Meaning \\
\hline$(90)$ & $\begin{array}{c}\text { /si-u-ka-ni-on-a/ } \\
\text { NEG-SM-FuT-OM-see-FV }\end{array}$ & $\begin{array}{l}\text { [su.ka.ni.o.na] } \\
* \text { [su.ka.no.na] }\end{array}$ & 'you (sg) will not see me' \\
\hline$(91)$ & $\begin{array}{c}\text { /si-u-ka-ni-uz-a/ } \\
\text { NEG-SM-FUT-OM-tell-Fv }\end{array}$ & $\begin{array}{l}\text { [su.ka.ni.u.za] } \\
* \text { [su.ka.nu.za] }\end{array}$ & 'you (sg) will not tell me' \\
\hline$(92)$ & $\begin{array}{c}\text { /u-a-ni-it-a/ } \\
\text { 1SM-PST-OM-call-FV }\end{array}$ & $\begin{array}{l}\text { [wa.ni.i.ta] } \\
* \text { [wa.ni.ta] }\end{array}$ & 'you (sg) called me' (hodiernal) \\
\hline$(93)$ & $\begin{array}{c}\text { /u-a-va-uz-a/ } \\
\text { 1SM-PST-OM-tell-Fv }\end{array}$ & $\begin{array}{l}\text { [wa.va.u.za] } \\
* \text { [wa.vu.za] }\end{array}$ & 'he/she told them' (hodiernal) \\
\hline (94) & $\begin{array}{c}\text { /mu-a-tfi-umb-a/ } \\
\text { 1SM-PST-OM-mould-FV }\end{array}$ & $\begin{array}{l}{\left[\mathrm{m}^{\mathrm{w}} \text { a.ffi.u. }{ }^{\mathrm{m}} \mathrm{ba}\right]} \\
*\left[\mathrm{~m}^{\mathrm{w}} \text { a.fu. }{ }^{\mathrm{m}} \mathrm{ba}\right]\end{array}$ & 'you moulded it' (hodiernal) \\
\hline
\end{tabular}

Note that in these examples, the vocalic hiatus within the Inflectional Stem is resolved through elision (90-91), glide formation (92-93) and secondary articulation (94). These examples illustrate the generalisation that we have stated earlier - that resyllabification occurs within the Inflectional Stem in ciNsenga to resolve vowel hiatus. Note, however, that the vocalic hiatus between the object marker and the stem in each of these examples is not resolved, which leaves the stem-initial vowel onsetless. Simango and Kadenge (2014) observe that hiatus across the stem domain in ciNsenga verbs does not trigger hiatus resolution. They note that the stem boundary is co-extensive with the verb root and posit a high-ranked alignment constraint for ciNsenga which requires perfect matching of the left edge of the verb root and the left edge of the syllable. The different hiatus resolution strategies available in this language - glide formation, secondary articulation and vowel elision - are all blocked because they would cause a mismatch between the left edge of the verb root and left edge of the syllable. The alignment constraint that blocks these strategies in this domain is ALIGN (ROOTVERB, $L, \sigma, L$ ), defined as follows:

ALIGN (ROOT $\mathrm{VERB}, \mathrm{L}, \sigma, \mathrm{L})$

The left edge of a verb root (=stem) corresponds to the left edge of a syllable

(Simango and Kadenge 2014:93)

Roberts-Kohno (1995) suggests that the left edge of the root for the verbs in (90-94) contains an empty $\mathrm{C}$ node (for a consonant that has since been lost), and that this $\mathrm{C}$ blocks hiatus resolution because it functions as the onset for $\mathrm{V}_{2}$. Although this proposal seems to account for the ciNsenga facts on diachronic grounds, it does not account for the facts in chiShona, shown in Table 11 below:

Table 11. Spreading across the Prosodic Stem boundary in chiShona

\begin{tabular}{|c|c|c|c|}
\hline & Underlying & Surface & Meaning \\
\hline$(96)$ & $\begin{array}{c}/ \text { u-u-on-a/ } \\
\text { 1SM-OBJ-see-FV }\end{array}$ & [u.wu.wo.ne] & 'you see it' \\
\hline$(97)$ & $\begin{array}{c}/ \text { ku-i-on-a/ } \\
\text { INF-OBJ-see-FV }\end{array}$ & [kujiwona] & 'to see it' \\
\hline$(98)$ & $\begin{array}{c}/ \text { i-a-on-a/ } \\
\text { 9SM-PST-see-FV }\end{array}$ & [jawona] & 'it saw' \\
\hline
\end{tabular}


ChiShona triggers glide epenthesis in the same context where ciNsenga tolerates vowel hiatus. Thus we dispense with Roberts-Kohno's suggestion that there is an empty $\mathrm{C}$ node in this position, and follow Simango and Kadenge (2014) in pursuing a synchronic OT account which posits a constraint that requires an alignment of the verb root and the left edge of a syllable. Note that in chiShona hiatus is resolved not only between the object marker and the Inflected Verb Stem as well as between the tense marker and the Inflected Stem, but also between a prefix vowel and a stem-initial vowel (i.e. across the Prosodic Stem boundary). The generalisation that emerges from these data is that whilst resyllabification, in the form of elision, glide formation and secondary articulation, operates within the Inflectional Stem (i.e., across the subject marker and TAM boundary), glide epenthesis is the optimal repair strategy across Prosodic Stem edges. As noted by Mudzingwa (2010:157), the constraint that blocks secondary articulation, elision and glide formation across stem boundaries is ALIGNL-PSTEM, and is defined in (99):

\section{ALIGNL-PSTEM}

The left edge of a Prosodic Stem must coincide with the left edge of a syllable

(Mudzingwa 2010:158)

The relative ordering of ONSET, ALIGN (ROOTVERB, $L, \sigma, L$ ) and ALIGNL-PSTEM is what gives rise to the difference between ciNsenga and chiShona with respect to how the two languages deal with vowel hiatus across the Prosodic Stem boundary. In ciNsenga, AliGN (ROOTVERB, L, $\sigma, L$ ) outranks both ONSET and ALIGNL-PSTEM whereas in chiShona ONSET outranks both ALIGNLPSTEM and ALIGN (ROOT $\mathrm{VERB}, \mathrm{L}, \sigma, \mathrm{L}$ ). The relevant derivations are presented in Tableaux 7 and 8:

Tableau 7. Vowel hiatus across the Prosodic Stem boundary in ciNsenga

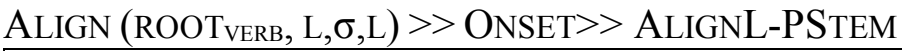

\begin{tabular}{|c|c|c|c|}
\hline /si1..u2.ka.ni ${ }_{1 . o_{2} . n a /}$ & "ALIGN (ROOT $\left.{ }_{\text {VERB }}, \mathrm{L}, \sigma, \mathrm{L}\right)$ & ONSET & ALIGNL-PSTEM \\
\hline$\sigma^{\circ}$ a. $\left[\mathrm{su}_{2} \cdot \mathrm{ka} \cdot \mathrm{ni}_{1} \cdot \mathrm{o}_{2} \cdot \mathrm{na}\right]$ & & $*$ & \\
\hline 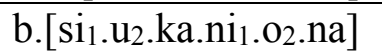 & & !** & \\
\hline c. $\left[\mathrm{su}_{2} \cdot \mathrm{ka} \cdot \mathrm{no}_{2} \cdot \mathrm{na}\right]$ & $* !$ & & $*$ \\
\hline 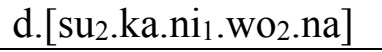 & $* !$ & & \\
\hline
\end{tabular}

Candidate (a) deletes the [i] of the negative marker [si-] and does not resolve hiatus between the object marker and the verb root. As a result, the candidate satisfies the high-ranked alignment constraint ALIGN (ROOTVERB, L, $\sigma, \mathrm{L}$ ). This constraint effectively blocks any repair strategy that may cause a mismatch between the left edge of a verb root and the left edge of a syllable. Candidate (a) is the optimal candidate although it violates ONSET. Candidate (b) retains vocalic hiatus in both the Inflectional Stem and the MacroStem, and satisfies the high-ranked ALIGN (ROOT VERB, $\mathrm{L}, \sigma, \mathrm{L}$ ). It is, however, non-optimal because it violates ONSET twice, unlike (a) which violates this constraint only once. Candidate (c) deletes $\mathrm{V}_{1}$ and resyllabifies the root-initial $\mathrm{V}_{2}$. As a result, it is eliminated by the high-ranked constraint Align (ROOTVERB, $L, \sigma, L$ ). Candidate (d), which uses glide epenthesis within the MacroStem, makes a fatal violation of ALIGN (ROOTVERB, L, $\sigma, L$ ). As mentioned earlier, glide epenthesis is the optimal repair strategy across Prosodic Stem boundaries in chiShona; this detail is formalised in Tableau 8. 
Tableau 8. Glide epenthesis across the Prosodic Stem boundary in chiShona

ONSET, ALIGNL-PSTEM $>>$ ALIGN (ROOT $\left.{ }_{\mathrm{VERB}}, \mathrm{L}, \sigma, \mathrm{L}\right)$

\begin{tabular}{|c|c|c|c|}
\hline$/ \mathrm{ku}_{1}-\mathrm{o}_{2} \mathrm{na} /$ & ONSET & ALIGNL-PSTEM & ALIGN $\left(\right.$ ROOT $\left._{\text {VERB }}, \mathrm{L}, \sigma, \mathrm{L}\right)$ \\
\hline a. $\left[\mathrm{ku}_{1} \cdot \mathrm{o}_{2 .} . \mathrm{na}\right]$ & $* !$ & & \\
\hline 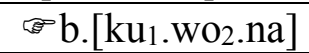 & & & $*$ \\
\hline c.[kwo2.na] & & $* !$ & * \\
\hline d. $\left[\mathrm{k}^{\mathrm{w}} \mathrm{O}_{2 .} \mathrm{na}\right]$ & & $* !$ & $*$ \\
\hline e.[ko2.na] & & $* !$ & * \\
\hline
\end{tabular}

The faithful parse (a) is eliminated by the inviolable constraint ONSET. Candidate (b) resolves hiatus through glide epenthesis which is the optimal strategy across the Prosodic Stem boundary. Furthermore, (b) satisfies the high-ranked constraints ONSET and ALIGNL-PSTEM and, as a result, is the optimal candidate. Candidate (c), which resolves hiatus through glide formation, fatally violates the high-ranked ALIGNL-PSTEM. It could also be eliminated by *COMPLEX. Candidates (d) and (e) eliminate hiatus through secondary articulation and elision, respectively. Consequently, both candidates fatally violate the high-ranked ALIGNL-PSTEM. In (100) and (101), we provide a summary of the constraint rankings in chiShona and ciNsenga, respectively. The constraints that are ranked differently in the two languages are italicised.

\section{ChiShona}

(100) OnSET, ALIGNL-PSTEM, *COMPLeX, *V:, AnCHOR L, $* \mathrm{C}^{\varsigma}, * \mathrm{C}^{\mathrm{j}},{ }^{*} \mathrm{C}^{\mathrm{w}} \mathrm{V}_{\mathrm{LAB}}, *$ LOWGLIDE $>>$ MAX-IO(RT) $>>\operatorname{MAX}-\mathrm{IO}(\mu), \operatorname{ALIGN}_{\left(R^{\prime} O O T_{\text {VERB }}, L, \sigma, L\right)}$

\section{CiNsenga}

$$
\begin{aligned}
& \text { ALIGN }\left(\text { ROOT }_{\text {VERB }}, L, \sigma, L\right)>>\text { ONSET }>>\text { ALIGNL-PSTEM, } \text { *COMPLEX, *V:, ANCHOR L, } \\
& { }^{*} \mathrm{C}^{\mathrm{s}},{ }^{*} \mathrm{C}^{\mathrm{j}},{ }^{*} \mathrm{C}^{\mathrm{W}} \mathrm{V}_{\mathrm{LAB}},{ }^{*} \text { LOW-GLIDE }>>\operatorname{MAX}-\mathrm{IO}(\mathrm{RT})>>\operatorname{MAX}-\mathrm{IO}(\mu)
\end{aligned}
$$

\section{Conclusion}

What has been demonstrated in this article is that vocalic hiatus is dispreferred in ciNsenga and chiShona, as it is in many languages of the world. It has been shown that both languages utilise glide formation, secondary articulation and elision to resolve vowel hiatus in the nominal and verbal domains. Glide formation operates when $V_{1}$ is [+high] and onsetless. When $V_{1}$ is $/ u$ / and is preceded by a consonant, secondary articulation is used as labialised consonants are allowed; when $\mathrm{V}_{1}$ is $/ \mathrm{i} /$, elision operates because palatalised consonants are banned in both languages. Elision is also triggered when $\mathrm{V}_{1}$ is /a/ because pharyngealised consonants and low glides are prohibited in both languages. Although the same hiatus repair strategies apply in both languages, a typological difference is evident within verbs, specifically across the Prosodic Stem boundary: in ciNsenga hiatus resolution is blocked, while in the same domain in chiShona vowel hiatus has to be resolved through glide epenthesis. By positing that ONSET is ranked lower than ALIGN (ROOT ${ }_{\mathrm{VERB}}, \mathrm{L}, \sigma, \mathrm{L}$ ) in ciNsenga, and that ONSET and ALIGNL-PSTEM are inviolable in chiShona, we have accounted for the variation between the two languages. 


\section{Abbreviations and symbols used in this article}

$\begin{array}{ll}\text { ALIGNL } & \text { align left } \\ \text { C } & \text { consonant } \\ \text { CL } & \text { noun class } \\ \text { C }^{\mathrm{W}} & \text { labialised consonant } \\ \mathrm{C}^{\text {C }} & \text { pharyngealised consonant } \\ \text { C }^{\mathrm{j}} & \text { palatalised consonant } \\ \text { FUT } & \text { future tense } \\ \text { FV } & \text { final vowel } \\ \text { INF } & \text { infinitive } \\ \text { IFS } & \text { inflectional final suffix } \\ \text { L } & \text { left } \\ \text { OBJ } & \text { object } \\ \text { OCP } & \text { Obligatory Contour Principle } \\ \text { OM } & \text { Object marker } \\ \text { OT } & \text { Optimality Theory } \\ \text { NEG } & \text { negative marker } \\ \text { PASS } & \text { passive } \\ \text { PSTEM } & \text { prosodic stem } \\ \text { PST } & \text { past tense } \\ \text { RED } & \text { reduplicative } \\ \text { RT } & \text { root node } \\ \text { Sg } & \text { singular } \\ \text { SM } & \text { subject marker } \\ \text { TAM } & \text { tense-aspect-mood } \\ \text { V } 1 & \text { first vowel } \\ \text { V } & \text { second vowel } \\ V_{\text {LAB }} & \text { labial vowel } \\ / / & \text { input (underlying representation) } \\ {[]} & \text { output (surface representation) } \\ \sigma & \text { syllable } \\ \mu & \text { mora } \\ \rightarrow & \text { is realised as } \\ * & \text { syllable boundary } \\ \# & \text { ungrammatical } \\ \text { * } & \text { word boundary } \\ & \text { optimal candidate } \\ & \end{array}$

\section{Acknowledgement}

Earlier versions of this paper were presented at the 2013 Annual Conference of the Linguistic Society of Southern Africa (LSSA) at the University of Stellenbosch, and at the Conference on the Phonetics and Phonology of Sub-Saharan Languages (in memory of Professor Tony Traill), at the University of the Witwatersrand in July 2013. We are grateful to the audiences at both conferences for their encouragement and to two anonymous reviewers for their useful comments and suggestions. All errors, however, remain our responsibility. 


\section{References}

Casali, R.F. 1997. Vowel elision in hiatus contexts: Which vowel goes? Language 73: 493-533.

Casali, R.F. 1998. Resolving hiatus. New York: Garland.

Casali, R.F. 2011. Hiatus resolution. In M. van Oostendorp, C.J. Ewen, E. Hume and K. Rice (eds.) The Blackwell companion to phonology. Malden, MA and Oxford: Wiley Blackwell Publishers. pp. 1434-1460.

Clements, G.N. and E. Hume. 1995. The internal organization of speech sounds. In J. Goldsmith (ed.) The handbook of phonological theory. Oxford: Blackwell. pp. 245-506.

Clements, G.N. and S.J. Keyser. 1983. CV phonology: A generative theory of the syllable. Cambridge, MA: MIT Press.

Downing, L.J. 2006. Canonical forms in prosodic morphology. Oxford: Oxford University Press.

Downing, L.J. and M. Kadenge. 2014. Prosodic stems in Shona. Paper presented at The Prosodic Hierarchy in a Typological Perspective Workshop, 14-15 March 2014, Stockholm University, Stockholm.

Fortune, G. 1955. An analytical grammar of Shona. Longman: London.

Fortune, G. 1980. Shona grammatical constructions. Harare: Mercury Press.

Good, G. 2005. Reconstructing morpheme order in Bantu: The case of causativization and applicativization. Diachronica 22: 3-57.

Harford, C. 1997. When two vowels go walking: Vowel coalescence in Shona. ZAMBEZIA: Journal of Humanities of the University of Zimbabwe 24(1): 69-85.

Hayes, B. 1989. Compensatory lengthening in moraic phonology. Linguistic Inquiry 20(2): 235305.

Ito, J. 1989. A prosodic theory of epenthesis. Natural Language \& Linguistic Theory 7(2): 217259.

Kadenge, M. 2008. The Phonology of Nambya. Unpublished PhD thesis, University of Zimbabwe.

Kadenge, M. 2010. Hiatus contexts and hiatus resolution strategies in Zezuru. Southern African Linguistics and Applied Language Studies 28(1): 1-11.

Kager, R. 1999. Optimality Theory. Cambridge: Cambridge University Press.

Katamba, F. 1989. An introduction to phonology. London and New York: Longman. 
Liphola, M.M. 2001. Aspects of phonology and morphology of Shimakonde. Unpublished PhD dissertation, Ohio State University.

Masagbor, G.A. 1989. Glide formation and vowel elision processes in Ivie (North Ibie). Journal of West African Languages VIX(1): 87-103.

McCarthy, J. 2008. Doing Optimality Theory: Applying theory to data. Malden, MA: Blackwell Publishing.

Mchombo, S.A. 1999. Quantification and verb morphology: The case of reciprocals in African languages. Linguistic Analysis 29: 182-213.

Mkanganwi, K.G. 1995. Shona: A grammatical sketch. Unpublished manuscript, University of Zimbabwe.

Miti, L. 2001. A linguistic analysis of ciNsenga: A Bantu language spoken in Zambia and Malawi. CASAS Book Series No. 16. Cape Town: The Centre for Advanced Studies of African Society.

Mtenje, A. 1992. Extralinguistic constraints on rule application in Chichewa and Chiyao phonology. African Languages and Cultures 5(1): 65-73.

Mtenje, A. 2007. On recent trends in phonology: Vowel sequences in Bantu languages. SOAS Working Papers in Linguistics 15(2007): 33-48.

Myers, S. 1987. Tone and the structure of words in Shona. Unpublished PhD dissertation, University of Massachusetts.

Mudzingwa, C. 2010. Shona morphophonemics: Repair strategies in Karanga and Zezuru. Unpublished PhD dissertation, University of British Columbia.

Mudzingwa, C. 2013. Hiatus resolution strategies in Karanga (Shona). Southern African Linguistics and Applied Language Studies 31(1): 1-24.

Mudzingwa, C. and M. Kadenge. 2011. Comparing hiatus resolution in Karanga and Nambya: An Optimality Theory account. Nordic Journal of African Studies 20(3): 203-240.

Mudzingwa, C. and M. Kadenge. 2013. An analysis of the ghost augment in chiShona. South African Journal of African Languages 33(1): 87-93.

Odden, D. and M. Odden. 1999. Kihehe syllable structure. In H. van der Hulst and R.A. Ritter (eds.) The syllable: Views and facts. New York: Mouton de Gruyter. pp. 417-445.

Prince, A. and P. Smolensky. 2004. Optimality Theory: Constraint interaction in generative grammar. Malden, MA: Blackwell.

Roberts-Kohno, R. 1995. Vowel coalescence and hiatus in Kikamba. In A. Akinlabi (ed.) Theoretical approaches to African linguistics. New Jersey: Africa World Press. pp. 313-328. 
Rogers, E. 2009. Phonetic evidence for complex Cw segments: An ultrasound and audio-visual study of Shona. Qualifying paper, University of British Columbia.

Rosenthall, S. 1994. Vowel/Glide Alternation in a Theory of Constraint Interaction. Unpublished $\mathrm{PhD}$ dissertation, University of Massachusetts.

Rosenthall, S. 1997. The distribution of prevocalic vowels. Natural Language \& Linguistic Theory 15(1): 139-180.

Senturia, M.B. 1998. A prosodic theory of hiatus resolution. Unpublished $\mathrm{PhD}$ thesis, University of California.

Sibanda G. 2009. Vowel sequences in Nguni: Resolving the problem of unacceptable VV sequences. In M. Matondo, F. McLaughlin and E. Potsdam (eds.) Selected proceedings of the $38^{\text {th }}$ Annual Conference on African Linguistics: Linguistic Theory and African Language Documentation. Somerville, MA: Cascadilla Proceedings Project. pp. 38-55.

Simango, S.R. 2006. Verb agreement and the syntax of ciNsenga relative clauses. Southern African Linguistics and Applied Language Studies 24(3): 277-290.

Simango, S.R. 2009. Causative disguised as stative: The affix -ik/-ek in ciCewa. Southern African Linguistics and Applied Language Studies 27(2): 121-134.

Simango, S.R. 2012. Subject marking, coordination and noun classes in ciNsenga. Southern African Linguistics and Applied Language Studies 30(2): 171-183.

Simango, S.R. 2013. An analysis of vowel harmony in ciNsenga and ciCewa: A comparative study. Southern African Linguistics and Applied Language Studies 31(2): 139-150.

Simango, S.R. and M. Kadenge. 2014. Vowel hiatus resolution in ciNsenga: An Optimality Theory analysis. Southern African Linguistics and Applied Language Studies 32(1): 79-96.

Zerbian, S. 2012. Morpho-phonological and morphological minimality in Tswana monosyllabic stems (Southern Bantu). In T. Stolz, N. Nau and C. Stroh (eds.) Monosyllables: From phonology to typology. Berlin: Akademie Verlag. pp. 131-148. 